\title{
Matrix-Assisted Laser Desorption \\ Ionization-Time of Flight Mass Spectrometry \\ (MALDI-TOF MS) Applications in Bacteriology: \\ Brazilian Contributions
}

\author{
Flávia Lúcia Piffano Costa Pellegrino * \\ Thiago Pavoni Gomes Chagas ** \\ Maria Silvana Alves *** \\ Ana Paula d'Alincourt Carvalho Assef **** \\ Donat Alexander Chapeaurouge ***** \\ Marise Dutra Asensi ${ }^{* * * *}$
}

\begin{abstract}
Among its innumerous applications in Bacteriology, the Matrix-Assisted Laser Desorption Ionization-Time of Flight Mass Spectrometry (MALDI-TOF MS) technique is evolving as a powerful tool for bacterial identification and antimicrobial resistance investigation. Publications have evaluated the MALDI-TOF MS performance in the identification of a series of bacterial pathogens, including the most common severe infectious agents, emergent pathogens involved with outbreaks of healthcare-associated infections, rare pathogens, and those whose isolation in culture media is difficult. As compared to conventional methods of bacterial identification, MALDI-TOF MS has proven to be a fast, accurate and cost-effective technique. Currently, MALDI-TOF MS has been used in antimicrobial resistance studies, since it has shown to be an efficient tool in detecting specific resistance mechanisms in bacteria, such as beta-lactamases production, for example. Here, we describe the advances in this growing field of mass spectrometry applied to Bacteriology, including Brazilian contributions.
\end{abstract}

Keywords: MALDI-TOF MS; Bacterial Infections and Mycoses; Clinical Laboratory Techniques.

\section{INTRODUCTION}

The ideal microbiological diagnostic should be efficient, fast and able to distinguish microorganisms causing the illness from non-infectious agents.

The proteomic technology "Matrix-Assisted Laser Desorption Ionization-Time of Flight Mass Spectrometry (MALDI-TOF MS)" has been introduced in clinical microbiology laboratories around the world and has since been useful for different purposes in diagnosis: fast and accurate bacterial identification (CHERKAOUI et al., 2010; JAMAL; ALBERT; ROTIMI, 2014), investigation of bacterial resistance mechanisms (SPARBIER et al., 2012; CARVALHAES et al., 2013; HRÁBAK; CHUDÁCKOVÁ; WALKOVÁ, 2013) and detection of the presence of specific bacterial clones (CABROLIER et al., 2015).
MALDI-TOF MS offers numerous advantages for the microbiological diagnostic (SENG et al., 2009; LAVIGNE et al., 2013; WIESER et al., 2012): 1. Bacterial identification results are ready more quickly than the conventional tests; 2 . Is accurate and sensitive, requiring small bacterial biomass [about 104 - 106 CFU (Colony Forming Unit)] being therefore interesting for the "slow growth pathogens" identification or for those do not grow well in culture; 3. Does not depend on metabolic reactions, being useful for the fastidious bacteria identification 4. Is able to identify, by the same system, Gram-negative and Gram-positive pathogens of medical significance, and 5. Its straightforward and easy methodology improves the productivity and decreases operating cost.

* *Laboratórios Integrados de Pesquisa em Bactérias Resistentes aos Antimicrobianos e em Desenvolvimento Galênico - LIPE, Unidade de Farmácia, Centro Universitário Estadual da Zona Oeste - UEZO, Campo Grande - RJ. E-mail: flpellegrino@hotmail.com

** Departamento de Patologia, Faculdade de Medicina, Universidade Federal Fluminense - UFF, Niterói - RJ.

*** Laboratório de Bioatividade Celular e Molecular, Centro de Pesquisas Farmacêuticas, Faculdade de Farmácia, Universidade Federal de Juiz de Fora - UFJF, Juiz de Fora - MG.

**** Laboratório de Pesquisa em Infecção Hospitalar, Instituto Oswaldo Cruz, Fundação Oswaldo Cruz, Rio de Janeiro - RJ.

***** Laboratório de Toxicologia, Instituto Oswaldo Cruz - FIOCRUZ, Rio de Janeiro - RJ. 
In addition, MALDI-TOF MS has been used as an efficient tool to detect bacterial resistance to antimicrobial agents (JUNG et al., 2014).

The main objective of the present review article is to emphasize the importance of MALDI-TOF MS as a powerful and useful tool in the diagnosis of bacterial pathogens, showing clinically relevant reports in Bacteriology, using this technology. The specific objectives include the different applications of MALDI-TOF MS in the bacterial identification, in the detection of bacterial pathogens directly from clinical specimens and in the detection of the bacterial virulence and resistance, focusing on the Brazilian studies that explore this promising methodology.

This review was built based on a bibliographic search using the PubMed option into the US National Library of Medicine National Institutes of Health homepage (https://www.ncbi.nlm.nih.gov/pubmed), which contains thousands of quotes from the biomedical literature of the Medline database. There were included 55 references, published in English, and considered relevant in the central theme of this article review that addresses the applications of MALDITOF MS technology in scientific investigations with bacteria of medical importance.

\section{ReVIEW OF THE Literature:}

\section{MALDI - TOF MS APPLICATIONS IN}

\section{BACTERIOLOGY}

\subsection{Bacterial identification by MALDI- -TOF MS}

\subsubsection{Sample preparation methodolo- gies}

Technically, there are different sample-preparation ways for bacterial identification by MALDI-TOF MS (WIESER et al., 2012): bacterial colonies obtained from pure cultures or bacterial products such as proteins or lipids obtained by extraction methods.

In case of the direct use of bacterial colonies, a bacterial colony cultured in an appropriate agar medium is mixed in an organic benzoic acid solution (benzoic acid or cinnamic acids) referred as matrix. The analyte and the matrix are then applied to a MALDI-TOF plate (MATTHIESEN; MUTENDA, 2007; SENG et al., 2009; WIESER et al., 2012; PATEL, 2015). The final solution (analyte plus matrix) crystallizes and the plate is inserted into the equipment at high vacuum (CHERKAOUI et al., 2010; SAFFERT et al., 2011; JAMAL; ALBERT; ROTIMI, 2014).

The analysis is triggered when the analyte is exposed to short laser pulses and the energy from the laser [usually ultraviolet (UV) or infrared (IR) light] desorbs the co-crystallized mixture of bacterial isolate and matrix, resulting in the ionization of the proteins. Ions are accelerated by a strong electric voltage and enter in a vacuum tube where they are separated depending on their molecular mass. The lighter ions arrive earlier on the detector than the heavier ones. In this way, a mass spectrum is usually created in the mass range from 2 $\mathrm{kDa}$ to $20 \mathrm{kDa}$. This mass spectrum represents the "fingerprint" of the microorganism. Due to the highly conserved composition in many bacterial species and because they are less influenced by culture conditions, ribosomal proteins ionized during the process, make the analysis highly reproducible.

In summary, after bacterial growth in agar media (1), one pure bacterial colony is applied to a MALDI plate (2-3). Later, the matrix is added to the same plate (4) and kept drying (co-crystallized) for some minutes (5). Target plate is placed into the equipment for

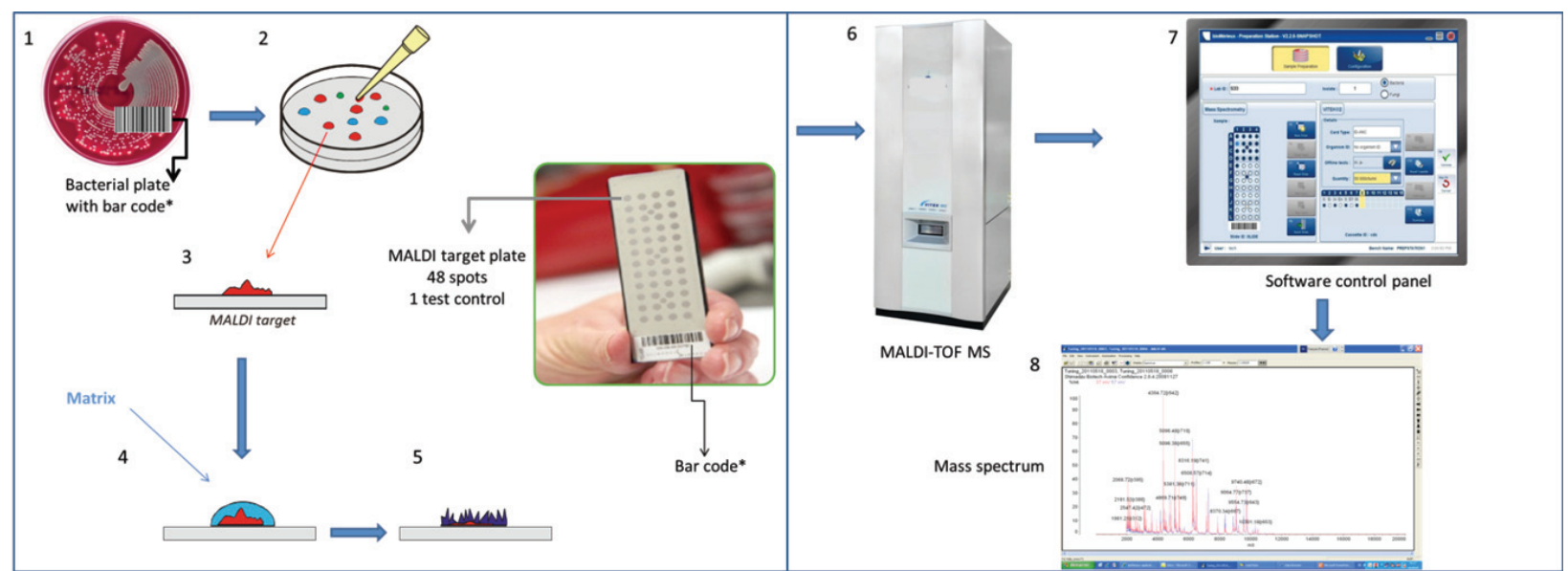

Figure 1: Matrix-Assisted Laser Desorption Ionization-Time of Flight Mass Spectrometry (MALDI-TOF MS) methodology applied to bacterial identification. 
MALDI-TOF MS analyzes (6). By bar code, in both, bacterial plate and in the MALDI plate, is possible to locate the registered isolate position (7). The spectrometer measures the mass-to-charge ratio of the proteins present in the isolate and a mass spectrum is generated (8). Finally, the equipment automatically compares the generated spectrum with spectra from known bacteria contained in the software database and concludes the bacterial identification (Figure 1).

Many microorganisms can be directly analyzed by MALDI-TOF MS because the on-plate treatment with organic solvents in combination with strong acid releases the cytosolic proteins. However, microorganisms as Nocardia, Actinomycetes and Mycobacteria, for example, need more drastic protein extraction procedures due to their impenetrable cell walls (CLARK et al., 2013).

MALDI-TOF MS has been reported as a reliable and expedited method for Mycobacteria identification. Unlike most bacteria, which can be directly placed onto a MALDI-TOF plate, Mycobacteria requires inactivation and extraction steps prior to analysis for access to proteins in the cells. The inactivation step is commonly performed with heat-killing and/or ethanol. For optimal results, mycobacterial proteins must be extracted from the cells, most commonly by silica bead beating, given the poorly permeable and mycolic acid-rich cell wall. Each of these steps and protocols, in addition to the breadth and depth of the MALDI reference databases, may introduce assay variability and influence the analytical performance characteristics of the method (MATHER; RIVERA; BUTLER-WU, 2014).

A study assessed the Biotyper (Bruker), Saramis and Vitek ${ }^{\circledR}$ MS version 3.0 (bioMérieux) performances for identification of 157 mycobacterial isolates by MALDI-TOF MS. In the Biotyper method, bacterial isolates were submitted to inactivation by heat and treated with ethyl alcohol, acetronitrile and formic acid solutions. In the Vitek MS, isolates were mixed with silica beads and ethyl alcohol, mechanically disrupted by vortex and treated with ethyl alcohol, acetonitrile and formic acid. Biotyper correctly identified $133(84.7 \%)$ isolates with no misidentifications (score cutoff value $\geq 1.8$ ). Saramis correctly identified $134(85.4 \%)$ isolates with one misidentification (confidence value $\geq 90 \%$ ) and Vitek MS correctly identified 140 (89.2\%) isolates with one misidentification (confidence value $\geq 90 \%$ ). Vitek MS showed to require fewer repeat analyses, which can represent an advantage. This study demonstrated that the three databases provided reliable identification for most mycobacterial species (WILEN; McMULLEN; BURNHAM, 2015).
A work reported the MALDI-TOF MS use for Staphylococcus identification and antimicrobial resistance determination based on the fatty acid profiles obtained by metal-oxide laser ionization mass spectrometry (CeO2-MOLI MS FA). The results have shown that CeO2-MOLI MS FA profiling is useful to differentiate methicillin-resistant Staphylococcus aureus (MRSA) and methicillin-sensitive Staphylococcus aureus (MSSA) (SAICHEK et al., 2016). Other studies have suggested that $\mathrm{CeO} 2$-catalyzed fragmentation of lipids to produce fatty acids using the laser energy inherent to MALDI-TOF MS is an interesting alternative to the misidentified microorganisms by protein-based methods (LA SCOLA; RAOULT, 2009; STEVENSON; DRAKE; MURRAY, 2010). By this methodology, it is possible to identify a series of bacteria at species level as Enterobacteriaceae family members, Acinetobacter and Listeria (COX et al., 2015).

\subsubsection{Bacterial direct identification from clinical specimens}

Because bloodstream infections (BSIs) are serious and fatal infections, the rapid microbiological diagnostic is essential to promptly institute optimal antibiotic therapy. Conventional biochemical tests used in microbiological routine usually take 24-48 hours. Molecular biology methods are faster than biochemical tests to detect bacterial pathogens in blood cultures, taking about 6 hours. Nevertheless, a novel alternative is the MALDI-TOF MS application in the identification of BSIs pathogens directly from blood cultures vials with the results available within 2 hours. This might lead to a faster diagnostic and the possibility to identify non-cultivable bacteria (KOK et al., 2011).

MALDI-TOF use to identify pathogens directly from blood specimens may generate a strong clinical impact mainly in Gram-negative bacteremia, where the brief information about the agent causing the infection and of its susceptibility pattern contributes to the discriminated choice of antibiotics to the treatment and may increase the chances of success on therapy (KOK et al., 2011; JO et al., 2016). MALDITOF MS has been considered a simple, rapid, accurate and cost-effective method for direct bacterial identification from positive blood cultures bottles (LA SCOLA; RAOULT, 2009; STEVENSON; DRAKE; MURRAY, 2010; JAMAL; SALEEM; ROTIMI, 2013; MONTEIRO et al., 2015; BARBERINO et al., 2017).

Urinary tract infections (UTI) are among the most common infections whose microbiological confirmation takes 24-48 hours once the microbiological diagnostic requires the bacterial cells count and the susceptibility determination to

HU Revista, Juiz de Fora, v. 43, n. 3, p. 285-294, jul./set. 2017 
antimicrobial agents. Some works have shown the possibility to identify bacterial pathogens directly from urine by MALDI-TOF MS (FERREIRA et al., 2011a; FERREIRA et al., 2011b; BURILLO et al., 2014).

Prior to MALDI-TOF MS analysis, different methods have been employed for the samples preparation: the intact bacterial cell method; the extraction method of bacterial proteins and the lysisfiltration technique associated with MALDI-TOF MS (LA SCOLA; RAOULT, 2009; KOK et al., 2011; FARINA et al., 2015; JO et al., 2016).

A study has compared two different methods for identifying pathogens directly from urine and blood specimens by MALDI-TOF MS. In the intact cell method, urine or blood are submitted to centrifugation to remove the blood cells. Supernatant is centrifuged to collect bacteria. The pellet obtained is washed with de-ionized water and applied onto a MALDI plate. In the ethanol-formic acid extraction method, the pellet obtained in the previous method is treated with chemical agents (ethanol, formic acid and acetonitrile) and supernatant is applied on the MALDI plate. According to this study, the intact cell method has shown excellent results for urine cultures and the extraction method was useful as complementary method to improve the microorganism identification directly from blood (FERREIRA et al., 2011b).

\subsubsection{MALDI-TOF MS data analysis}

The identification of the "fingerprint" mass spectrum of a microorganism is achieved by a comparative search of the list of the protein masses against a database where the corresponding data of different bacterial species are stored. The result of the interrogation of the database is shown as a list of microorganisms ranked by a "score" (numerical value). The highest score reveals the best match between the experimental mass spectrum and the spectrum found in the database (SENG et al., 2009).

Different criteria (outlined by the manufacturer or modified criteria) have been applied for the interpretation of bacterial identification results by MALDI-TOF MS (SENG et al., 2009; SAFFERT et al., 2011).

An American study compared the BD Phoenix automated microbiology system to MALDI-TOF MS for Gram-negative bacilli identification (MONTEIRO et al., 2015). MicroFlex LT system was used to MALDI-TOF MS and the spectra were analyzed using Bruker Biotyper 2.0 software. The database contained 3,740 spectra from 319 genera and 1,946 species of microorganisms. As manufacturer criteria, a score $\geq 2.0$ was used to indicate species level; score of 1.7 to 1.999 to indicate genus; and $<1.7$ was interpreted as no identification. For validation, a minimum difference of $10 \%$ between the top score and next closest score was required for individual isolates (named " $10 \%$ differential rule"). Identifications that failed the " $10 \%$ rule" were incorrect. Results showed Bruker Biotyper MALDI-TOF MS presented a better performance than BD Phoenix system for identification of rare Gram-negative bacteria. For common isolates, both systems were equivalent (SAFFERT et al., 2011).

A French study evaluated the MALDI-TOF MS performance (Bruker Daltonics), using modified score values (Biotyper software): score $\geq 1.9$ indicated species, 1.7 to 1.9 indicated genus and $<1.7$ indicated no identification. Isolate was considered correctly identified when 2 of 4 spectra had score $\geq 1.9$ for species identification or score $\geq 1.7$ for genus identification. MALDI-TOF MS correctly identified $84 \%$ of 1,660 bacterial isolates at the species level, including fewer common species as Actinomyces spp., Bacteroides spp., Corynebacterium spp., Fusobacterium spp., Haemophilus spp. and Kingella kingae. The period required for bacterial identification of a single isolate was 6 minutes and all bacterial identifications were available for the clinicians in about 2 hours. No discrepancy between MALDI-TOF MS and Gram staining in terms of bacterial identification was observed (SENG et al., 2009).

\subsubsection{MALDI-TOF MS performance in bacterial identification}

Numerous publications reported MALDI-TOF MS applications on identification of diverse bacterial groups, genus or species such as Enterobacteriaceae (BIBERG et al., 2015), non-fermenting bacteria (MELLMANN et al., 2008), Staphylococcus spp. (DUBOIS et al., 2010), Neisseria (ILINA et al., 2009), Clostridia (GROSSE-HERRENTHEY et al., 2008), Mycobacteria (PIGNONE et al., 2006), Helicobacter pylori (PEREIRA et al., 2006), Campylobacter (MARTINY et al., 2011), Mycoplasma hominis (PAILHORIÈS et al., 2014) and some Haemophilus species (FRICKMANN et al., 2013).

MALDI-TOF MS has been used for identification of staphylococci and enterococci clinical isolates, including methicillin-resistant staphylococci (MRS) and vancomycin-resistant enterococci (VRE). A study analyzed suspected bacterial colonies and positive blood cultures vials by MALDI-TOF MS. Interpretation criteria adopted a score $\geq 2.0$ to highest identification of species and score values of $<1.7$ (clinical isolates) and $<1.6$ (blood cultures) to distinct species. The study included 56 positive blood 
culture and 124 clinical isolates: MSSA (PantonValentine positive and negative), community-acquired MRSA (CA-MRSA), non-CA-MRSA, Enterococcus faecalis, Enterococcus faecium (vanA or vanB positive) and Enterococcus galinarum. MALDI-TOF MS reliably identified all clinical isolates and all enterococcal blood cultures $(100 \%$ concordance). The staphylococcal cultures from blood were identified with $97.5 \%$ concordance (CHAN et al., 2015).

MALDI-TOF MS faces difficulties as the misidentification of some bacterial species presenting homology of ribosomal proteins sequences. Among them are Streptococcuspneumoniae, Streptococcus mitis group and Streptococcus oralis (WERNO et al., 2012). Due to the similarity among the protein sequences, the mass spectra generated are also very similar, being therefore difficult to discriminate these species. A recent Brazilian work has described the MALDI-TOF MS potential as a useful tool for characterizing Streptococcus pneumoniae isolates by the determination of capsular types. The study analyzed 416 pneumococcal isolates of six serotypes highly prevalent in pneumococcal disease and nasopharyngeal by MALDI-TOF MS. The technique generated fast and high-quality results, applicable to clinical laboratories routine (PINTO et al., 2017).

\subsection{Bacterial resistance investigation by MALDI-TOF MS}

Since the problem of the bacterial resistance is noticeable, microbiology laboratories have included specific methods to investigate the presence of the main antimicrobial resistance mechanisms in bacteria, such as the production of beta-lactamases enzymes. However, the most of methods, mainly phenotypic tests, are time-consuming and must be performed by a highly skilled operator due to subjectivity and difficulty in interpretation.

Studies have shown the MALDI-TOF MS use in the bacterial resistance detection since it is possible to infer the presence of particular resistance mechanisms (SPARBIER et al., 2012; KEMPF et al., 2012). In bacteria beta-lactamase-producers, for example, is possible to analyze by MALDI-TOF MS if the antimicrobial drug (enzyme target) is being hydrolyzed, for example, and so to presume that the bacteria is resistant to that antimicrobial due the betalactamase production.

Some works have described similar procedures to study the bacterial resistance by MALDI-TOF MS. Bacterial suspensions obtained from fresh culture are prepared in buffer (Tris- $\mathrm{HCl}$ ) or $\mathrm{NaCl}$ solution, with or without serial dilutions of the antimicrobial drug to be tested. Suspensions are incubated for appropriate period ( 2 to 4 hours). Bacterial extracts are obtained by centrifugation. An aliquot of the supernatant is applied on the MALDI plate, where the same volume of matrix ( $\alpha$-cyano-4-hydroxycinnamic acid) is later added and kept drying at room temperature. The presence or the absence of peaks in MALDI spectrum, related to the drug tested, are observed. Positive results for the production of beta-lactamases, for example, can be the disappearance of specific peaks related to the drug during the incubation time or the appearance of specific peaks representing hydrolysis products of the drug tested (BURCKHARDT; ZIMMERMANN, 2011; CARVALHAES et al., 2013). For the tests, is crucial to establish the characteristic mass spectrum of the pure drug. The observation of specific peaks may indicate that the antibiotic is in solution and its hydrolysis may not have occurred. However, these results do not allow to affirm which the resistance mechanism involved (KEMPF et al., 2012; HRÁBAK; CHUDÁCKOVÁ; WALKOVÁ, 2013).

In bacterial resistance studies, MALDI-TOF MS has been used for many applications such as: to discriminate extended-spectrum betalactamases-producing Enterobacteriaceae and metallo-beta-lactamase-producing Pseudomonas aeruginosa (SCHAUMANN et al., 2012); to identify resistant Pseudomonas aeruginosa high-risk clones (CABROLIER et al., 2015); to discriminate MRSA lineages (SAICHEK et al., 2016); to identify VRE (GRIFFIN et al., 2012); to detect the production of carbapenemases in Pseudomonas aeruginosa and Acinetobacter baumannii (CARVALHAES et al., 2013) and to detect beta-lactamase activity directly from blood culture vials (CARVALHAES et al., 2014).

\section{Discussion}

\subsection{MALDI-TOF MS: Brazilian contri- butions}

\subsubsection{Bacterial virulence proteins de- tection}

In 2006, the MALDI-TOF MS analysis of Helicobacter pylori strains from chronic gastritis and duodenal ulcers was useful to identify bacterial proteins like GroEL and clarify the role of different proteins related to $H$. pylori pathogenesis (PEREIRA et al., 2006).

In 2009, the proteomic analysis of a Leptospira interrogans virulent strain was performed in a Brazilian study. Total protein extracts were separated by twodimensional gel electrophoresis (2-DE) and analyzed by MALDI-TOF MS. The mass lists obtained were analyzed by peptide mass fingerprinting on the server

HU Revista, Juiz de Fora, v. 43, n. 3, p. 285-294, jul./set. 2017 
MASCOT for matches with known protein sequences deposited on databases. From 895 spots analyzed, MALDI-TOF MS identified 286 leptospiral proteins presenting regulatory and metabolism functions in $L$. interrogans (VIEIRA et al., 2009).

In 2012, MALDI-TOF MS was used in the investigation of Corynebacterium diphtheriae nonfimbrial proteins, possibly also involved in the bacterial invasion process. By MALDI-TOF MS was possible to identify the 67-72 Da hemaglutinin directly implicated in bacterial invasion and apoptosis of epithelial cells in the early stages of diphtheria and invasive infections by $C$. diphtheriae (SABBADINI et al., 2012).

\subsubsection{Pathogenic bacteria identifica- tion in cystic fibrosis patients}

Fehlberg et al. (2013) evaluated MALDI-TOF MS performance for species identification of clinical isolates belonging to the Burkholderia cepacia complex. MALDI-TOF MS was able to identify $100 \%$ of the isolates at the genus level. A misidentification at the species level occurred in about $23 \%$ of the isolates, mainly with Burkholderia contaminants and the B. cepacia species (FEHLBERG et al., 2013).

MALDI-TOF MS can be a useful tool to identify a special group of bacteria called "uncommon glucose non-fermenting Gram-negative bacilli (UGNFGNB)", from respiratory samples of patients with cystic fibrosis. A retrospective study analyzed 76 bacterial isolates recovered from oropharyngeal swab cultures from children with cystic fibrosis. The MALDI-TOF MS power discriminatory was superior to the automated techniques and to conventional phenotypic methods, showing good concordance with DNA sequencing $(75 \%)$. The result is clinically relevant once the identification of the UGNFGNB microorganisms depends on their metabolic and physiological properties. Unlike the limitations observed by conventional and automatic techniques, MALDI-TOF MS is based on the ribosomal protein analyses and for this reason is potentially more accurate, efficient and faster (HOMEM DE MELLO DE SOUZA et al., 2014).

Other study compared MALDI-TOF MS with molecular biology methods in the identification of Achromobacter spp., an emergent pathogen of difficult characterization. Twenty-eight bacterial isolates were recovered from 16 cystic fibrosis patients attended in two reference centers in Rio de Janeiro. The two genotypic tools used (Multilocus Sequencing Typing and amplification and sequencing of an inner fragment of the bla $a_{\text {OXA-114 }}$ gene) presented good and similar results in the identification of
Achromobacter xylosoxidans and Achromobacter rublandii. However, MALDI-TOF MS proceeded an incorrect identification of $A$. rublandii, $A$. dolens and $A$. insuavis as $A$. xylosoxidans (RODRIGUES et al., 2015).

\subsubsection{Immunogenic bacterial proteins detection}

A study showed an interesting application of MALDI-TOF MS in the development of a possible immunotherapy against Acinetobacter baumannii infections. By MALDI-TOF MS, six immunoreactive proteins located on the surface of $A$. baumannii (OmpA, Omp34kDa, OprC, OprB-like, OXA-23 and ferric siderophore receptor protein) were identified. Results suggested these proteins could serve as antigen candidates for the development of vaccines and passive immunotherapies against $A$. baumannii infections (BONIN et al., 2014).

\subsubsection{Infectious diseases diagnosis, epidemiology and resistant bacteria studies}

Some Brazilian studies have focused on the bacterial identification by MALDI-TOF MS directly of clinical specimens for rapid diagnosis of infectious diseases such as vitreous humor-inoculated blood culture bottles for bacterial endophthalmitis diagnosis (TANAKA et al. , 2013) and BSI diagnosis (BARBERINO et al., 2017), showing that MALDI can provide accurate results to identify Gram-negative and Gram-positive bacteria, directly from blood, in a reduced time, optimizing the antimicrobial therapy.

Klebsiella pneumoniae identification has performed by MALDI-TOF MS in a Brazilian epidemiological study. Most bacterial isolates characterized as KPC2-producing Klebsiella pneumoniae presented a high resistance to ertapenem (BIBERG et al., 2015).

Other Brazilian study has evaluated the MALDITOF MS accuracy in detecting the hydrolytic activity of ecarbapenemase enzymes in Psendomonas aeruginosa and Acinetobacter baumannii isolates. Positive result for carbapenemases activity based on ertapenem hydrolysis, considered when the ertapenem intactmolecule mass peak $(475 \mathrm{~m} / \mathrm{z})$ and its monosodium salt $(497 \mathrm{~m} / \mathrm{z})$ completely disappeared. Carbapenemase activity was detected by MALDI-TOF MS in a 2 hours assay. This study concluded that MALDI-TOF MS is a rapid and attractive tool for the detection of carbapenemases activity in non-fermenters bacteria (CARVALHAES et al., 2013).

MALDI-TOF MS performance to detect carbapenemase activity directly from blood cultures vials was first evaluated in a Brazilian study. From 
110 bacterial isolates identified, $81.8 \%(90 / 110)$ was correctly identified by MALDI-TOF MS. All positive blood culture vials were submitted to carbapenemase assay. From 29 carbapenemase-producing isolates, MALDI-TOF MS detected the carbapenemase activity in 21 (72.4\%), especially those KPC-2 and SPM-1-producing isolates, showing to be a feasible and rapid test to identify carbapenemase activity directly from blood culture vials (CARVALHAES et al., 2014).

The influence of different culture media on detection of the carbapenemase activity using MALDI-TOF MS, was evaluated in other study. Enterobacteriaceae and glucose non-fermenting bacteria were grown on Müeller-Hinton agar, blood agar, MacConkey agar and ChromID CPS agar. According to this study, except the MacConkey agar, all the others culture media analyzed could be used with success $(100 \%$ of sensitivity and specificity) to detect the carbapenem hydrolysis by MALDI-TOF MS. When carbapenemase-producing bacteria were cultivated on MacConkey agar, MALDI-TOF MS and other phenotypic methods as the CarbaNP rapid test were not able to recognize them as carbapenemase producers (RAMOS et al., 2016).

\section{Conclusion}

Bacteriology faces changes with the MALDI-TOF MS technology introduction in Brazilian laboratories. MALDI-TOF MS seems to be an interesting alternative when compared to other phenotypic tests used in diagnostic, showing to be rapid and efficient for clinically relevant bacteria identification. Is still early to predict if MALDI-TOF MS technology will replace well-established conventional phenotypic methods. Nevertheless, MALDI-TOF MS contributions are increasing, as well as, its benefits and applications such as its use in bacterial resistance studies and in infectious diseases diagnosis mainly by the bacterial identification directly from the clinical samples.

\section{ACKNOWLEDGEMENTS:}

We thank to bioMérieux by the MALDI-TOF MS images, showed at Figure 1.

\section{Aplicações da Técnica de Espectrometria de Massa por lonização e Dessorção de Matriz com Laser em Tempo de Voo (MALDI-TOF MS) em Bacteriologia: Contribuições Brasileiras}

\section{RESUMO}

Dentre as suas inúmeras aplicações em Bacteriologia, a técnica de "Espectrometria de Massa por Ionização e Dessorção de Matriz com Laser em Tempo de Voo [Matrix-Assisted Laser Desorption Ionization-Time of Flight Mass Spectrometry (MALDI-TOF MS)]" tem evoluído como uma poderosa ferramenta para a identificação bacteriana e a investigação da resistência bacteriana aos antimicrobianos. Publicações tem avaliado o desempenho de MALDI-TOF na identificação de uma série de patógenos bacterianos, incluindo os agentes mais comuns de infecções graves, patógenos emergentes envolvidos com surtos de infecções associadas à saúde, patógenos raros, e aqueles de difícil isolamento em meios de cultura. Em comparação aos métodos convencionais de identificação bacteriana, MALDI-TOF MS provou ser uma técnica rápida, precisa e rentável. Atualmente, MALDI-TOF MS tem sido utilizado em estudos de resistência antimicrobiana, uma vez que tem mostrado ser uma ferramenta eficiente na detecção de mecanismos especificos de resistência em bactérias, como a produção beta-lactamases, por exemplo. Aqui, nós descrevemos os avanços neste crescente campo da espectrometria de massa aplicada à Bacteriologia, incluindo as contribuições brasileiras.

Palavras-chave: MALDI-TOF MS; Infecções Bacterianas e Micoses; Técnicas de Laboratório Clínico.

\section{REFERENCES}

BARBERINO, M. G. et al. Direct identification from positive blood broth culture by matrix-assisted laser desorption-ionization time-of-flight mass spectrometry (MALDI-TOF MS). Brazilian Journal of Infectious Diseases, v. 21, n. 3, p. 339-342, may./ jun. 2017.

BIBERG, C. A. et al. KPC-2-producing Klebsiella pneumoniae in a hospital in the Midwest region of Brazil. Brazilian Journal of Microbiology, v. 46, n. 2, p. 501-504, jun. 2015.
BONIN, R. F. et al. Identification of immunogenic proteins of the bacterium Acinetobacter baumannii using a proteomic approach. Proteomics Clinical Applications, v. 8, n. 11-12, p. 916-923, dec. 2014.

BURCKHARDT, I.; ZIMMERMANN, S. Using Matrix-Assisted Laser Desorption Ionization-Time of Flight Mass Spectrometry to detect carbapenem resistance within 1 to 2.5 hours. Journal of Clinical Microbiology, v. 49, n. 9, p. 3321-3324, sep. 2011. 
BURILLO, A. et al. Gram-stain plus MALDI-TOF MS (MatrixAssisted Laser Desorption Ionization-Time of Flight Mass Spectrometry) for a rapid diagnosis of urinary tract infection. PLoS ONE, v. 9, n. 1, p. e86915, jan. 2014.

CABROLIER, N. et al. Matrix-Assisted Laser Desorption Ionization-Time of Flight Mass Spectrometry identifies Pseudomonas aeruginosa high-risk clones. Journal of Clinical Microbiology, v. 53, n. 4, p. 1395-1398, apr. 2015.

CARVALHAES, C. G. et al. Detection of SPM-1-producing Pseudomonas aeruginosa and class D- $\beta$-lactamase-producing Acinetobacter baumannii isolates by use of Liquid ChromatographyMass Spectrometry and Matrix-Assisted Laser Desorption Ionization-Time of Flight Mass Spectrometry. Journal of Clinical Microbiology, v. 51, n. 1, p. 287-290, jan. 2013.

CARVALHAES, C. G. et al. Detection of carbapenemase activity directly from blood culture vials using MALDI-TOF MS: a quick answer for the right decision. Journal of Antimicrobial and Chemotherapy, v. 69, n. 8, p. 2132-2136, aug. 2014.

CHAN, W. S. et al. Complementary use of MALDI-TOF MS and real-time PCR-melt curve analysis for rapid identification of methicillin-resistant staphylococci and VRE. Journal of Antimicrobial and Chemotherapy, v. 70, n. 2, p. 441-447, feb. 2015.

CHERKAOUI, A. et al. Comparison of two Matrix-Assisted Laser Desorption Ionization-Time of Flight Mass Spectrometry methods with conventional phenotypic identification for routine identification of bacteria to the species level. Journal of Clinical Microbiology, v. 48, n. 4, p. 1169-1175, apr. 2010.

CLARK, A. E. et al. Matrix-Assisted Laser Desorption IonizationTime of Flight Mass Spectrometry: a fundamental shift in the routine practice of clinical microbiology. Clinical Microbiology Reviews, v. 26, n. 3, p. 547-603, jul. 2013.

COX, C. R. et al. Strain-level bacterial identification by $\mathrm{CeO} 2-$ catalyzed MALDI-TOF MS fatty acid analysis and comparison to commercial protein-based methods. Scientific Reports, v. 5, n. x, p. 10470, jul. 2015.

DUBOIS, D. et al. Identification of a variety of Staphylococcus species by Matrix-Assisted Laser Desorption Ionization-Time of Flight Mass Spectrometry. Journal of Clinical Microbiology, v. 48, n. 3, p. 941-945, mar. 2010.

FARINA, C. et al. Direct identification of microorganisms from positive blood cultures using the lysis-filtration technique and matrix-assisted laser desorption ionization time-of-flight mass spectrometry (MALDI-TOF MS): a multicentre study. New Microbiologica, v. 38, n. 2, p. 245-250, apr. 2015.

FEHLBERG, L. C. et al. Performance of MALDI-TOF MS for species identification of Burkholderia cepacia complex clinical isolates. Diagnostic Microbiology and Infectious Disease, v. 77, n. 2, p. 126-128, oct. 2013.
FERREIRA, L. et al. Microorganisms direct identification from blood culture by matrix-assisted laser desorption/ionization time-of-flight mass spectrometry. Clinical Microbiology and Infection, v. 17, n. 4, p. 546-551, apr. 2011a.

FERREIRA, L. et al. Rapid method for direct identification of bacteria in urine and blood culture samples by matrix-assisted laser desorption ionization time-of-flight mass spectrometry: intact cell vs. extraction method. Clinical Microbiology and Infection, v. 17, n. 7, p. 1007-1012, jul. 2011b.

FRICKMANN, H. et al. Rapid discrimination of Haemophilus influenzae, $H$. parainfluenzae, and $H$. haemolyticus by fluorescence in situ hybridization (FISH) and two Matrix-Assisted LaserDesorption-Ionization Time-of-Flight Mass Spectrometry (MALDI-TOF-MS) platforms. See comment in PubMed Commons belowPLoS ONE, v. 8, n. 4, p. e63222, apr. 2013.

GRIFFIN, P. M. et al. Use of Matrix-Assisted Laser Desorption Ionization-Time of Flight Mass Spectrometry to identify vancomycin-resistant enterococci and investigate the epidemiology of an outbreak. Journal of Clinical Microbiology, v. 50, n. 9, p. 2918-31, sep. 2012.

GROSSE-HERRENTHEY, A. et al. Challenging the problem of clostridial identification with matrix-assisted laser desorption and ionization-time-of-flight mass spectrometry (MALDI-TOF MS). Anaerobe, v. 14, n. 4, p. 242-249, oct. 2008.

HOMEM DE MELLO DE SOUZA, H. A. et al. MALDI-TOF: a useful tool for laboratory identification of uncommon glucose non-fermenting Gram-negative bacteria associated with cystic fibrosis. Journal of Medical Microbiology, v. 63, n. 9, p. 11481153, sep. 2014.

HRÁBAK, J.; CHUDÁCKOVÁ, E.; WALKOVÁ, R. MatrixAssisted Laser Desorption Ionization-Time of Flight (MALDITOF) Mass Spectrometry for detection of antibiotic resistance mechanisms: from research to routine diagnosis. Clinical Microbiology Reviews, v. 26, n. 1, p. 103-114, jan. 2013.

ILINA, E. N. et al. Direct bacterial profiling by Matrix-Assisted Laser Desorption-Ionization Time-of-Flight Mass Spectrometry for identification of pathogenic Neisseria. Journal of Molecular Diagnostics, v. 11, n. 1, p. 75-86, jan. 2009.

JAMAL, W.; SALEEM, R.; ROTIMI, V. O. Rapid identification of pathogens directly from blood culture bottles by Bruker matrixassisted laser desorption laser ionization-time of flight mass spectrometry versus routine methods. Diagnostic Microbiology and Infectious Disease, v. 76, n. 4, p. 404-408, aug. 2013.

JAMAL, W.; ALBERT, J. M.; ROTIMI, V. O. Real-time comparative evaluation of bioMérieux VITEK MS versus Bruker Microflex MS matrix-assisted laser desorption-ionization time-offlight mass spectrometry systems, for identification of clinically significant bacteria. BMC Microbiology, v. 14, n. x, p. 289, nov. 2014. 
JO, S. J. et al. Direct identification and antimicrobial susceptibility testing of bacteria from positive blood culture bottles by MatrixAssisted Laser Desorption/Ionization Time-of-Flight Mass Spectrometry and the Vitek 2 system. Annals of Laboratory Medicine, v. 36, n. 2, p. 117-123, mar. 2016.

JUNG, J. S. et al. Rapid detection of antibiotic resistance based on mass spectrometry and stable isotopes. European Journal of Clinical Microbiology \& Infectious Diseases, v. 33, n. 6., p. 949-955, dec. 2014.

KEMPF, M. et al. Rapid detection of carbapenem resistance in Acinetobacter baumannii using Matrix-Assisted Laser Desorption Ionization-Time of Flight Mass Spectrometry. PLoS ONE, v. 7, n. 2, p. e31676, feb. 2012.

$\mathrm{KOK}$, J. et al. Identification of bacteria in blood culture broths using Matrix-Assisted Laser Desorption Ionization Sensityper ${ }^{\mathrm{TM}}$ and Time of Flight Mass Spectrometry. PLoS ONE, v. 6, n. 8, p. e23285, aug. 2011.

LA SCOLA, B.; RAOULT, D. Direct identification of bacteria in positive blood culture bottles by Matrix-Assisted Laser Desorption Ionisation Time-of-Flight Mass Spectrometry. PLoS ONE, v. 4, n. 11, p. e8041, nov. 2009.

LAVIGNE, J-P. et al. Mass spectrometry: a revolution in clinical microbiology? Clinical Chemistry and Laboratory Medicine, v. 51, n. 2, p. 257-270, feb. 2013.

MARTINY, D. et al. Accuracy of the API Campy system, the Vitek 2 Neisseria-Haemophilus card and matrix-assisted laser desorption ionization time-of-flight mass spectrometry for the identification of Campylobacter and related organisms. Clinical Microbiology and Infection, v. 17, n. 7, p. 1001-1006, jul. 2011.

MATHER, C. A.; RIVERA, S. F.; BUTLER-WU, S. M. Comparison of the Bruker Biotyper and Vitek MS Matrix-Assisted Laser Desorption Ionization-Time of Flight Mass Spectrometry systems for identification of Mycobacteria using simplified protein extraction protocols. Journal of Clinical Microbiology, v. 52, n. 1, p. 130-138, jan. 2014.

MATTHIESEN, R.; MUTENDA, K. E. Introduction to Proteomics. In: MATTIESEN, R. Methods in Molecular Biology - Mass Spectrometry Data Analysis in Proteomics. New Jersey: Humana Press Inc., v. 367, p. 1-35, 2007.

MELLMANN, A. et al. Evaluation of Matrix-Assisted Laser Desorption Ionization-Time-of-Flight Mass Spectrometry in comparison to $16 \mathrm{~S}$ rRNA gene sequencing for species identification of nonfermenting bacteria. Journal of Clinical Microbiology, v. 46, n. 6, p. 1946-1954, jun. 2008.

MONTEIRO, J. et al. Fast and reliable bacterial identification direct from positive blood culture using a new TFA sample preparation protocol and the Vitek ${ }^{\circledR}$ MS system. Journal of Microbiological Methods, v. 109, n. x, p. 157-159, feb. 2015.
PAILHORIÈS, H. et al. A case report of Mycoplasma hominis brain abscess identified by MALDI-TOF mass spectrometry. International Journal of Infectious Diseases, v. 29, n. x, p. 166-168, dec. 2014.

PATEL, R. MALDI-TOF MS for the diagnosis of infectious diseases. Clinical Chemistry, v. 61, n. 1, p. 100-111, jan. 2015.

PEREIRA, D. R. B. et al. Comparative analysis of two-dimensional electrophoresis maps (2-DE) of Helicobacter pylori from Brazilian patients with chronic gastritis and duodenal ulcer: a preliminary report. Revista do Instituto de Medicina Tropical de São Paulo, v. 48, n. 3, p. 175-177, may./jun. 2006.

PIGNONE, M. et al. Identification of Mycobacteria by MatrixAssisted Laser Desorption Ionization-Time-of-Flight Mass Spectrometry. Journal of Clinical Microbiology, v. 44, n. 6, p. 1963-1970, jun. 2006.

PINTO, T. C. A. et al. Potential of MALDI-TOF MS as an alternative approach for capsular typing Streptococcus pneumoniae isolates. Scientific Reports, v. 28, n. 7, p. 45572, mar. 2017.

RAMOS, A. C. et al. Influence of culture media on detection of carbapenem hydrolysis by MALDI-TOF MS. Journal of Clinical Microbiology, v. 54, n. 7, p. 1896-1898, jul. 2016.

RODRIGUES, E. R. et al. Characterization of Achromobacter species in cystic fibrosis patients: comparison of bla $a_{\mathrm{OXA}-114}$ PCR amplification, Multilocus Sequence Typing, and Matrix-Assisted Laser Desorption Ionization-Time of Flight Mass Spectrometry. Journal of Clinical Microbiology, v. 53, n. 12, p. 3894-3896, dec. 2015.

SABBADINI, P. S. et al. Corynebacterium diphtheriae 67-72p hemagglutinin, characterized as the protein DIP0733, contributes to invasion and induction of apoptosis in HEp-2 cells. Microbial Pathogenesis, v. 52, n. 3, p. 165-176, mar. 2012.

SAFFERT, R. T. et al. Comparison of Bruker Biotyper MatrixAssisted Laser Desorption Ionization-Time of Flight Mass Spectrometer to BD Phoenix automated microbiology system for identification of Gram-negative bacilli. Journal of Clinical Microbiology, v. 49, n. 3, p. 887-892, mar. 2011.

SAICHEK, N. R. et al. Strain-level Staphylococcus differentiation by $\mathrm{CeO} 2$-metal oxide laser ionization mass spectrometry fatty acid profiling. BMC Microbiology, v. 16, n. x, p. 72, apr. 2016.

SCHAUMANN, R. et al. A step towards the discrimination of beta-lactamase-producing clinical isolates of Enterobacteriaceae and Psendomonas aeruginosa by MALDI-TOF mass spectrometry. Medical Science Monitor, v. 18, n. 9, p. 71-77, sep. 2012.

SENG, P. et al. Ongoing revolution in Bacteriology: routine identification of bacteria by Matrix-Assisted Laser Desorption Ionization Time-of-Flight Mass Spectrometry. Clinical Infectious Diseases, v. 49, n. 4, p. 543-551, aug. 2009. 
SPARBIER, K. et al. Matrix-Assisted Laser Desorption Ionization-Time of Flight Mass Spectrometry-based functional assay for rapid detection of resistance against $\beta$-lactam antibiotics. Journal of Clinical Microbiology, v. 50, n. 3, p. 927-937, mar. 2012.

STEVENSON, L. G.; DRAKE, S. K.; MURRAY, P. R. Rapid identification of bacteria in positive blood culture broths by Matrix-Assisted Laser Desorption Ionization-Time of Flight Mass Spectrometry. Journal of Clinical Microbiology, v. 48, n. 2, p. 444-447, feb. 2010.

TANAKA, T. et al. Bactec ${ }^{\mathrm{TM}}$ blood culture bottles allied to MALDI-TOF mass spectrometry: rapid etiologic diagnosis of bacterial endophthalmitis. Diagnostic Microbiology and Infectious Disease, v. 88, n. 3, p. 222-224, jul. 2017.

VIEIRA, M. L. et al. Proteome analysis of Leptospira interrogans virulent strain. The Open Microbiology Journal, v. 7, n. 3, p. 69-74, may. 2009.
WERNO, A. M. et al. Differentiation of Streptococcus pneumoniae from nonpneumococcal streptococci of the Streptococcus mitis group by Matrix-Assisted Laser Desorption Ionization-Time of Flight Mass Spectrometry. Journal of Clinical Microbiology, v. 50, n. 9, p. 2863-2867, sep. 2012.

WIESER, A. et al. MALDI-TOF MS in microbiological diagnostics-identification of microorganisms and beyond (mini review). Applied Microbiology and Biotechnology, v. 93, n. 3 , p. 965-974, feb. 2012.

WILEN, C. B.; McMullen, A. R.; BURNHAM, C.-A. D. Comparison of sample preparation methods, instrumentation platforms, and contemporary commercial databases for identification of clinically relevant Mycobacteria by MatrixAssisted Laser Desorption Ionization-Time of Flight Mass Spectrometry. Journal of Clinical Microbiology, v. 53, n. 7, p. 2308-2315, jul. 2015. 